\title{
Analysis of the Role of Digital Influencers and Their Impact on the Functioning of the Contemporary On-Line Promotional System and Its Sustainable Development
}

\author{
Janusz Wielki \\ Faculty of Economics and Management, Opole University of Technology, 45-036 Opole, Poland; janusz@wielki.pl \\ Received: 18 June 2020; Accepted: 26 August 2020; Published: 1 September 2020 \\ check for \\ updates
}

\begin{abstract}
Along with the increasingly high level of digital media consumption, organizations' expenditure on online promotional activities is constantly and dynamically growing. At the same time, together with the growing expenditures on digital promotion, it can be clearly seen that the effectiveness of activities carried out in the electronic space in its current form is decreasing. Therefore, in the new market situation, when the promotion of products and services has never been so difficult, organizations have started to look for other methods of influencing consumers. One of the most important trends is the use of the influencer marketing concept. In this context, the aim of this article is to analyze the role, place and significance of digital influencers in the overall functioning of the online promotional system, and the impact of the influencer marketing concept on its sustainable development. In order to implement it, a literature analysis was carried out on the origins of this phenomenon, and its scale, causes and impact on the functioning of the digital promotion system. After the completion of this stage of the research, a questionnaire survey was conducted on a group of individual Internet users in order to obtain primary data. The results of the research indicate that there is a great potential for activities involving digital influencers. This potential relates primarily to the effective transmission of information about a product or service, the impact on increased brand awareness, and the impact on the sales level of products and services offered by companies. The study also identified the most important threats that may affect the future development of the concept of influencer marketing.
\end{abstract}

Keywords: influencer marketing; digital promotional activities; advertising media mix; electronic space; Generation Z

\section{Introduction}

The level of digital media consumption is constantly growing. From 2012 to 2018, the daily level rose from $5 \mathrm{~h} 37 \mathrm{~min}$ to $6 \mathrm{~h} 45 \mathrm{~min}$ per person. An even higher level of digital media consumption is recorded for users from Generation $\mathrm{Z}$. In the age range 16-24 years, it is $7 \mathrm{~h} 44 \mathrm{~min}$ for a typical day. At the same time, it is clear that digital media consumption is rapidly shifting to smartphones at the expense of desktop computers, laptops and tablets. During the years 2012-2018, it increased from $1 \mathrm{~h}$ $17 \mathrm{~min}$ to $3 \mathrm{~h} 18 \mathrm{~min}$ [1].

In this situation, it is obvious that there is a continuous and extremely dynamic increase in expenditure on online promotional activities, manifested, among others, by a steady increase in expenditure on digital advertising, with decreasing expenditure on traditional media [2]. In 2019, digital advertising expenditure is expected to account for more than fifty percent of global advertising expenditure, with the highest growth rates recorded in mobile advertising [3]. At the same time, in 
countries such as the United Kingdom, China, Norway and Canada, digital has already become the dominant ad medium [4].

With increasing investments, what is clearly visible is the decreasing effectiveness of activities carried out in the electronic space [5,6]. There are a number of reasons for this situation. Undoubtedly, the fact that consumers are becoming a more and more complex group is an extremely important issue $[7,8]$. In this context, their susceptibility to the marketing activities applied to date is clearly visible; e.g., according to Harris Interactive, $90 \%$ of Americans ignore digital advertising [9]. This situation results from dissatisfaction with the ways the organizations use to communicate with them. In recent years, this has been clearly manifested by the development of the ad-blocking phenomenon $[10,11]$. Its main reasons are too many advertisements being displayed online, and their growing aggressiveness affecting the on-line user experience $[6,12,13]$. Another important factor is that users become aware of the hidden costs resulting from online ads, such as increased loading time and bandwidth consumption [14]. As a result, the development of ad-blocking leads to the collapse of one of the key online business models according to which advertisers pay publishers a certain amount of money for each display of their advertisement to a visitor on their Website. In this situation, many organizations are trying to improve the on-line user experience by using personalized marketing [15]. However, more and more research shows that this experience does not need to be improved by such an approach [16]. There are many different reasons for that. For example, some of those who block ads use ad-block solutions to curb on-line tracking, which hinders the data collection needed for personalized marketing [17]. As, in recent years, environmental issues became vital aspects for growing number of consumers, such concepts as green advertising [18] and environmental advertising [19] have become important trends in the case of promotional activities.

An important element in the evolving market is the growing presence of Generation Z, which is a growing group of consumers; e.g., in the US, they will account for $40 \%$ of all consumers by 2020 [14]. This is a generation that does not know reality without the Internet, for whom the world made up of technology and geographical constraints does not exist [15]; therefore, it is also referred to as "the first generation of true digital natives" [16]. It behaves completely differently, and completely different problems are important for them, compared to the previous generation of consumers; i.e., millennial cohorts [15]. Its representatives value individual expression and avoid labels. They can also be easily mobilized for various purposes (reasons). They make decisions in a highly analytical and pragmatic way. At the same time, as consumers, they are mostly well-educated as far as brands and their realities are concerned [20-23]. They are also environmentally conscious, caring about sustainable consumption [24].

This generation requires a completely different marketing approach from the organization, since, among other things, it is ceasing to pay attention to many of the advertising forms used so far. Spending a lot of time in social media [1,25], they willingly follow the persons present in it who they trust [26]. Therefore, in the new market situation, when promoting products, services or brands has never been so difficult, organizations have begun to look for alternative methods of influencing consumers [27]. One of the most important trends is the use of the concept of influencer marketing [28-30]. This concept is understood as "marketing practice that takes advantage of well-followed online users, who are able to influence consumers' attitudes and decision-making processes in favor of brands or ideas" [31]. The concept belongs to one of three main types of online media channels: earned media (the other two are paid media and owned media) [32]. Influencer marketing has become the fastest growing trend in terms of communication with customers, and the number of its campaigns and posts has grown exponentially year-over-year from 2015 onwards [33,34]. This changes the functioning of entire industries [35,36], being a critical element for success in many of them [37]. As shown by studies completed by McKinsey \& Company in India, the power of digital influencers can be truly significant. According to their results, $80 \%$ of consumers will consider a new brand based on the recommendation of a key influencer [38]. At the same time, in many cases, they are becoming a new type of a local partner, referred to as a local digital influencer, without the participation of whom it is difficult to imagine companies' expansion into new foreign markets [39]. Meanwhile, the differences in the 
impact exerted by digital influencers on Generation $\mathrm{Z}$ consumers compared to other groups are clearly visible [40]. According to the Harvard Business Review, 19\% of American consumers bought goods or services in 2018 as a result of the recommendations of a digital influencer. In the group of consumers who are below 25, this percentage was almost twice as high; i.e., it amounted to $36 \%$ [41].

The growing significance of digital influencers is also confirmed by organizations increasing the expenditure allocated to this form of marketing activities. As shown by various studies, the scale of use of influencers in the marketing activities of organizations is constantly growing. According to the Influencer Marketing Benchmark Report: 2020, the value of influencer marketing as an industry is projected to increase from USD 1.7 billion in 2016 to USD 6.5 billion in 2019, and USD 9.7 billion in 2020 [42]. The data from the report prepared by Business Insider Intelligence are even more optimistic. According to them, the value of the influencer marketing industry will amount to USD 8 billion in 2019, and will reach USD 15 billion in 2022 [43]. The growing value of the industry can be seen, for example, in the number of new platforms and influencer marketing focused agencies. It increased from 190 to 1120 between 2015 and 2019, and by as much as 380 between 2018 and 2019 [42].

In the context of the above-presented market trends, the aim of this article is to analyze the role, place and significance of digital influencers in the overall functioning of the on-line promotional system, and the impact of the concept of influencer marketing on its sustainable development. In this regard, sustainable development is understood as such development of this system that utilizes, in the most balanced way, all available - now and in the future-means of digital promotion in order to achieve optimum results in the process of marketing communication with customers, taking into consideration CSR issues.

The primary research conducted for this article addressed respondents belonging to Generation Z; i.e., the group of consumers for whom this form of marketing activity is particularly important. The aim was to fill the existing research gap concerning the real significance of digital influencers and the scope of their impact on Generation Z. The literature provides very little, inconsistent information in this respect.

\section{Digital Influencers-Concept and Typology}

Although the idea of using various types of known or influential people and characters within the concept of influencer marketing seems to be closely related to the extremely dynamic development of social media [44], its roots in fact are a few centuries earlier. They date back to the 1760s, with the pioneer being Josiah Wedgwood, who produced ceramics for the British royal family. Other important figures for the development of the concept appeared in the 19th and 20th centuries [45]. On the other hand, the key to the development of the contemporary version of word-of-mouth marketing is the Internet's entry into the Web 2.0 phase. It is related to the fact that its modern version is closely related to the extremely dynamic development of social media, and their growing use in the marketing activities of organizations formed in the electronic space [46-49]. The emergence of social media has dramatically changed the ways in which consumers communicate and create bonds, both among themselves and with brands [50]. In this respect, the concept of social media marketing was developed [49,50]. It was with the growing popularity of these media that persons began to appear, gathering groups of supporters around themselves, in some cases even as many as over a hundred million people [51] (see Figure 1).

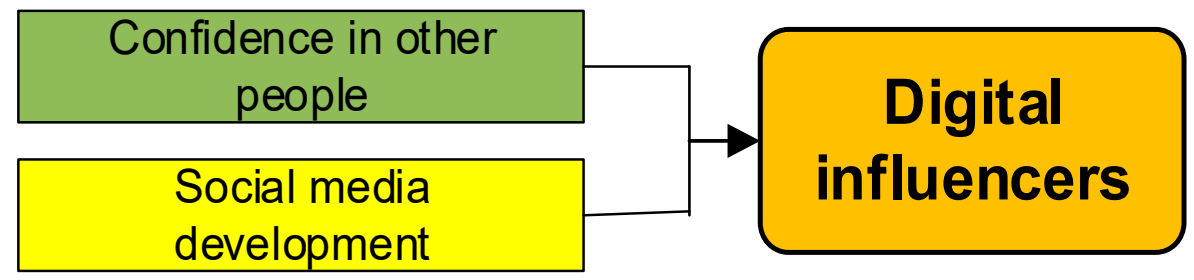

Figure 1. Two main sources of growing popularity of digital influencers (source: own source). 
Organizations perceive influencers as opinion leaders, mediating in the distribution of information and facilitating its dissemination to their on-line followers [52,53]. As a result, they are becoming spokespersons or ambassadors for their brands [54-56]. Organizations use them to support traditional marketing activities, and to generate a multiplier effect based on electronic word of mouth, playing an important role in building a 'digital relationship' with their clients $[57,58]$. In today's market conditions, they perceive the digital relationship as an extremely important factor [59].

The last few years have been period in which organizations have become strongly interested in the use of digital influencers in their marketing activities, and have allocated more and more of their promotional budgets to this form of activity, which results from the aforementioned decreasing effectiveness of the other forms of digital promotion used so far [60]. According to Oxford Dictionaries, this new marketing trend is also clearly visible through the use of the word 'influencer'. Its monthly use more than doubled between 2012 and 2017 [61]. The dynamically growing-over the last few years-interest in the 'influencer' and 'influencer marketing' concepts can also be seen in the Google Trends service [62,63].

As far as the influencer notion is concerned, according to Kartajay, Kotler and Setiawan, these are "persons respected in their communities, who have a large group of committed supporters and audience" [64]. It is also emphasized that they very often create their own specific content (user-generated content [65]) to build their reputation, and that they are considered experts in their communities. This type of content is created, inter alia, as a result of the increasing spread of the celebrity culture [66]. According to [57], "influencers are powerful human brands that positively impact the performance of companies associated with them". With respect to the use of the Internet, they are referred to as online influencers. Influencers perceived in this way are defined as "any type of person who publishes online who has a significant following" [32]. A more extended definition of influencers understood in this way is presented in [45]: an "influencer is an opinion leader, popular in a wider or higher group of regular recipients, who, with his or her credible actions-currently conducted more and more often on the Internet-inspires trust, engages and convinces the addressees of his or her communication to make specific choices, such as those related to shopping, nutrition or worldview". In the context of their use of social media, they are referred to as social media influencers $[25,67]$. For influencers understood in this way, two other definitions are more relevant. According to the first one, "influencers are a type of micro-celebrity who have accrued a large number of followers on social media and frequently use this social capital to gain access to financial resources [68]". In the context of their use of social media, a different definition is more appropriate. According to Oxford Dictionaries, the other definition refers to an influencer as "a person with the ability to influence potential buyers of a product or service by promoting or recommending it in social media". It is in this context that they are understood in this article [61].

Several categories of digital influencers can be distinguished, and their taxonomy can be made according to their different characteristics. The most elementary division is presented in Figure 2, and three groups are distinguished within its framework. Within the first of them, influencers are divided by their range, which is connected with the number of people who follow them. In this context, several categories of influencers can be distinguished. Namely: celebrities (over 5 million), mega influencers ( 1 million-5 million), top influencers (over 500 thousand), macro-influencers (100-500 thousand), middle level influencers (20 thousand-100 thousand), micro-influencers (less than 20 thousand) and nano-influencers (1 thousand-10 thousand) $[45,69,70]$. 


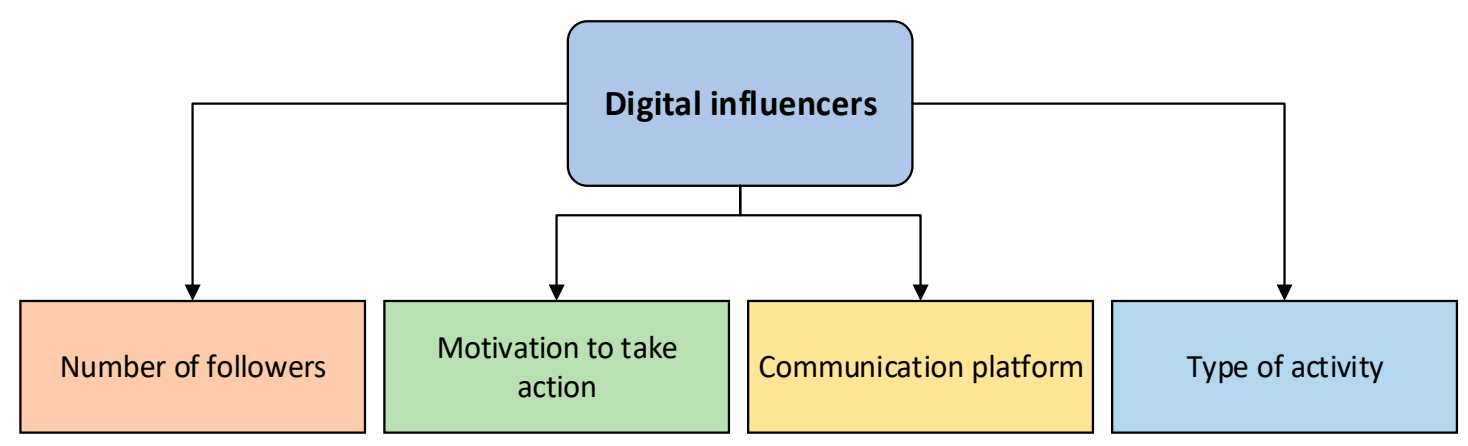

Figure 2. Taxonomy of digital influencers according to four main categories (source: own source based on $[9,45,69-72])$.

Influencers can also be divided according to their motivation to take action. In this context, the following categories can be distinguished: idols, experts, lifestylers, activists, and artists. The first group consists of people who are highly recognizable and popular. In their messages, they focus mainly on themselves, intertwining other topics into their message (e.g., political, social or related to current affairs). The second group consists of persons who are recognized as authorities in a given field due to their knowledge or skills. This group of influencers includes industry specialists, consultants, reviewers, or testers. Lifestylers, on the other hand, are people who get involved in discussions about lifestyle and leisure activities. Their content is mainly related to fashion, beauty, health, interior decoration, cooking and travel. In the case of another group, i.e., activists, their hallmark is the worldview they present. These are most often Internet users interested in such topics as environmental protection, minority rights or feminism. Their content promotes specific ideas and lifestyles. As far as the category of artists is concerned, it mainly includes persons focusing on creating material with high aesthetic and visual appeal. These are most often Internet users running various types of photoblogs or Instagram profiles. They deal with a variety of aspects, such as travel, nature, people and architecture $[9,34,45]$.

The third way by which influencers can be categorized is according to the communication platform they use. Bloggers, YouTubers, Facebookers, Instagramers, Twitterers, Snapchaters or TikTokers can be distinguished within this group [45]. This last, youngest group of influencers is connected with the TikTok application, which is mainly used by persons aged 13-17 years. In recent years, the application has recorded the highest dynamics of downloads [42]. At the same time, it should be noted that different social platforms are developed and used by influencers in different geographical areas, ones that are completely unknown in other regions. Examples include WeChat, Tencent QQ or Sina Weibo, which are extremely popular in China, but completely unknown, for example, in Europe [73].

Finally, digital influencers can be divided according to one more criterion, into two groups: active and passive influencers. The former includes those who are targeted by companies to promote their products or services. The latter encompasses those who are not directly targeted by companies [72].

\section{Key Benefits and Challenges Related to the Use of Digital Influencers in Organizations' Promotional Activities}

There is a whole range of reasons for using digital influencers in the marketing activities of an organization, and a range of benefits resulting from such activities. Undoubtedly, the key and most frequently raised issue in all reports and studies is the connection between the content transmitted and a specific person. The influencer's authentic message induces the trust of the recipients, and allows relationships to be built with the recipients $[34,45,53,74,75]$. This is extremely important in today's market conditions. According to Nielsen's research, $92 \%$ of consumers worldwide trust user-generated content and word-of-mouth recommendations more than they trust advertising. Consequently, the activities of influencers lead to the humanization of the brand and improved awareness of its existence [34,76-78]. An important issue connected with the activities involving the use of digital 
influencers is also the opportunity of easier access to precisely selected groups of recipients to deliver the content [34,45].

Research conducted by Nielsen Catalina Solutions also indicates that activities involving influencers contribute to increased sales of products. Their results indicate that the respondents subjected to the influence of digital influencers purchased significantly more than the reference group [79]. They confirm earlier research conducted in 2012 by Hubspot and Market Force. According to the former, $71 \%$ of consumers are more likely to make purchases based on social media referrals [80]. On the other hand, according to the latter, $78 \%$ of consumers' purchases are impacted by companies' social media posts [81]. Global consumer research conducted by Rakuten Marketing at the turn of December 2018 and January 2019 also indicates the impact of influencers on product sales. According to the results, $80 \%$ of the respondents made the purchase recommended by the influencer by clicking on the link or image [82].

An extremely important issue in the context of using influencers in the marketing activities of an organization is that they are highly cost-effective. This is confirmed by the results of various research. According to the 'Influencer Marketing Benchmarking Report: 2020', companies with a good understanding of the activities in the area of influencer marketing obtain high average earned media values of up to USD 18 per dollar spent on influencer marketing. Even average companies benefit from a return of USD 5.78 per dollar spent on influencer marketing in 2019 [42]. Compared to 2018, this increased from USD 5.20 [83]. The results of the research carried out by TapInfluence, together with Nielsen Catalina Solutions, in cooperation with one of the Fortune 500 food brands, are even more optimistic. According to their results, marketing campaigns based on the use of digital influencers generate USD 23 per dollar spent. For the best banners, it is USD 4.30, and for 'average' banner ads, it is USD 2.15 [84].

As far as the prospects for using influencer marketing are concerned, according to 'The State of Influencer Marketing 2018' report, 39\% of the surveyed companies planned to increase the budget for activities in this area in 2018, considering them to be effective [85]. In turn, according to the aforementioned 'Influencer Marketing Benchmarking Report: 2019', 86\% of the surveyed companies intended to allocate a part of their 2019 budgets to activities involving digital influencers. In 2017, this percentage was $37 \%$. At the same time, $63 \%$ of the surveyed companies intended to increase the share of expenditures on influencer marketing in the following year [83]. The results of subsequent studies indicate a growing trend in this area, and estimate it at $66 \%$ in 2020 [42]. This trend is also confirmed by the research conducted on the Polish market among four hundred persons representing companies operating in various industries. According to their results, $46.2 \%$ of the surveyed companies planned to increase their budgets for influencer marketing in 2019 [45]. This trend is also confirmed by the results of the global eMarketer survey conducted among 226 marketing managers (Chief Marketing Officers). According to them, $30.5 \%$ of the respondents pointed to increasing their focus on influencer marketing as an element of the advertising media mix [86].

At the same time, it should be noted that despite the relative freshness of activities in the influencer marketing area, a number of emerging challenges can be observed, along with threats related to this form of online promotion. Undoubtedly the most important of them is the influencer fraud phenomenon, related to the fact that some of the accounts or profiles following influencers do not belong to real people, but are only false accounts (fake followers), being the result of bots' activities [87]. As a result of the occurrence of fraudulent 'influencers', a significant part of the funds spent on activities in influencer marketing is wasted. According to the Points North Group report, out of USD 744 million that brands spent on influencer marketing in 2018, USD 102 million was wasted on fake followers [88]. In the context of building trust in influencers, which is critical from the viewpoint of their effectiveness, a very dangerous trend is the phenomenon of influencers suggesting they participate in promotional activities for a particular company, while in fact this is not the case. At the heart of such activities (fake sponsored content) lies the conviction of influencers (or rather people who aspire to be influencers) that the more sponsors they have, the more trust in them they will gain. The phenomenon has become 
so widespread that, in many cases, it is difficult to be sure whether or not certain content is really sponsored [89]. The results of the study conducted for the Influencer Marketing Benchmark Report: 2020 show that influencer fraud is an increasing concern for respondents. More than $2 / 3$ of them have experienced various forms of influencer frauds [42].

Another important challenge connected with influencer marketing is the change in the algorithms 'controlling' content delivery to users on social media platforms (social algorithm changes), making the content presented by influencers less visible for the target groups [90].

\section{Materials and Methods}

The aim of the article is to analyze the role and place of digital influencers in the functioning and sustainable development of the digital advertising ecosystem, and the impact of the influencer marketing concept on the processes of its transformation. In order to achieve this goal, a literature analysis was conducted on the genesis, dynamics and directions of the development of the phenomenon and its economic aspects. After the analysis of the secondary data in order to obtain primary data, a questionnaire survey was conducted on a group of individual Internet users. The questions were formulated based on the completed literature analysis. The selection of the group on which the research was conducted was based on purposive sampling, and resulted from two issues. First of all, the aim was to ensure that the persons participating in the research belong to the circle of persons who use the Internet, and use social media intensively. The literature analysis and previous studies clearly show that students are definitely such persons [6]. Secondly, it was important for the survey to include persons from the so-called Generation Z; namely, people born in the mid-1990s and later. As the literature analysis shows, Internet users from this generation are particularly susceptible to marketing activities involving digital influencers, and will constitute a target group in the coming years, which is important from the point of view of marketing activities [91]. Therefore, taking account of both of the above factors, the sample consisted of full-time first- and second-degree students. At the same time, it should be noted that, despite the fact that the selection of the population for the survey was a deliberate choice, the survey itself was conducted on randomly selected groups of students. It was assumed that a group of about one hundred respondents from each faculty would be surveyed.

The research aimed at acquiring primary data was carried out in the period from 14 January 2019 to 16 May 2019, and covered full-time students from all six main faculties of the Opole University of Technology; i.e., the Faculty of Electrical Engineering, Automatic Control and Informatics (WEAiI); the Faculty of Mechanical Engineering (WM); the Faculty of Construction and Architecture (WBiA); the Faculty of Economics and Management (WEiZ); the Faculty of Production Engineering and Logistics (WIPiL); and the Faculty of Physical Education and Physiotherapy (WWFiF). Due to a marginal number of students, the research did not include students from the non-local faculty; i.e., the Faculty of Technical Systems Engineering. Despite the fact that the selection of the population for the studies was deliberate, the studies were carried out on randomly selected groups of students. These were groups consisting of up to fifteen students who had laboratory classes (i.e., classes involving computers with Internet access). All students from the groups filled in the questionnaire during laboratory classes conducted at their faculties. This procedure of sampling was used because, due to personal data protection and the General Data Protection Regulation in force in Poland, it is not possible to gain access to the personal data of university students and carry out their individual random sampling. The whole sampling procedure is presented in Figure 3. 


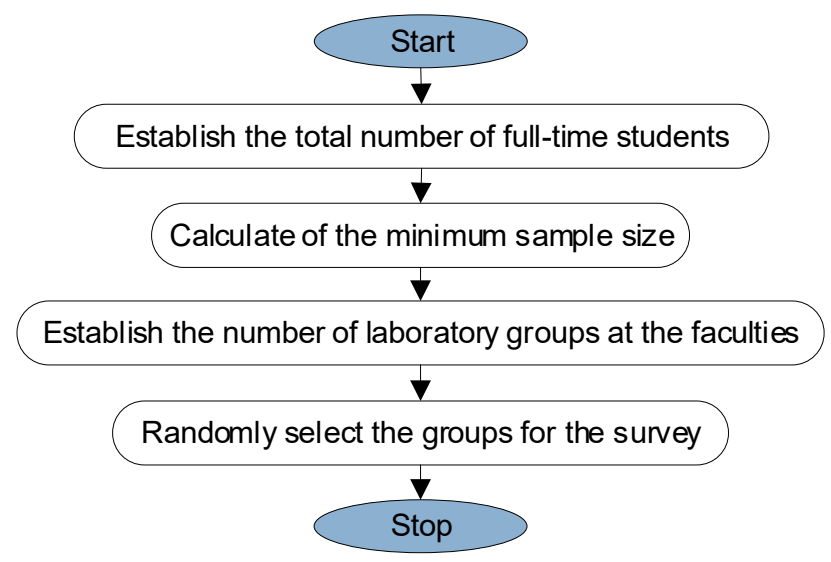

Figure 3. Sampling procedure (source: own source).

In total, the survey covered a group of 612 respondents (about 100 people from each of the faculties covered by the study), and assumed questionnaires completed directly with the use of Google Forms (the total number of full-time students at the Opole University of Technology is 3059). In terms of gender, $54 \%$ of the respondents were men, whereas $46 \%$ were women. In terms of educational level, $77.1 \%$ of respondents were undergraduate students, whereas $23 \%$ were graduate students (see Table 1 ). The research questionnaire comprised thirteen closed questions and eight sociodemographic questions. A Likert scale was used in the case of the four closed questions.

Table 1. Educational level of respondents.

\begin{tabular}{cccccccc}
\hline Faculty & WEiZ & WIPIL & WBiA & WEAiI & WWFiF & WM & Average \\
\hline undergraduate & $81.3 \%$ & $85.9 \%$ & $70.4 \%$ & $76.6 \%$ & $73.2 \%$ & $75.0 \%$ & $77.1 \%$ \\
graduate & $18.8 \%$ & $14.1 \%$ & $29.6 \%$ & $23.4 \%$ & $26.8 \%$ & $25.0 \%$ & $23.0 \%$ \\
\hline \multicolumn{7}{c}{ Source: own elaboration on the basis of survey results. }
\end{tabular}

In the context of the conducted primary research, the representativeness of the examined sample was assessed using the following formula:

$$
n>\frac{N}{1+\frac{4 d^{2}(N-1)}{u_{1-\frac{\alpha}{2}}^{2}}}
$$

$N=3059$ (number of full-time students at the Opole University of Technology)

$d=5 \%$, which is $0.05, u_{1-\frac{\alpha}{2}}^{2}=1.96$.

The representative sample calculated from the above formula is $n>341$. As 612 randomly selected respondents took part in the survey, the results obtained in the survey should be considered sufficient to be generalized to the entire population.

In questions in which the respondents assessed certain issues or phenomena, the five-level Likert scale was used. The questionnaire consisted of thirteen basic questions and a respondents' particulars section.

The following research hypothesis (H1) was adopted in the article: "Digital influencers using social media have more and more influence on promotional activities of the organization, changing more and more comprehensive functioning of on-line promotional system". At the same time, two auxiliary hypotheses were formulated: "There is a relationship between the manner in which respondents use the Internet and their knowledge of the digital influencer concept" (H2). "There is a dependence between the use of ad-block solutions by the respondents and the opinion they express, concerning the use of digital influencers by organizations in their promotional activities given the increasingly common advertisement blocking" (H3). 
The hypotheses were formulated based on the completed literature analysis (see Sections 1-3), also taking into account the results of the author's previously published studies (see [6]). It relates mainly to $\mathrm{H} 3$, but also $\mathrm{H} 2$. When it comes to $\mathrm{H} 2$, based on the results of previous research presented in [6] and the literature analysis on Generation Z, it was assumed that respondents belonging to this group are very intensive users of the Internet and social media. In this context, it was hypothesized that along with increasing users on-line activity, the probability that they have chance to encounter the concept of the digital influencer and its practical utilization is growing. Literature analysis on the ad-blocking phenomenon and our own previously-conducted research lead to the formulation of H3. The results of our own research, presented in [6], clearly indicate the common usage of ad-block solutions by students. Therefore, it was assumed that, as they block traditional forms of digital ads, this group will be interested in alternative forms of on-line promotional activities, such as influencer marketing and perspectives of their development in the context the ad-blocking phenomenon's growth.

A wide range of secondary data was obtained to verify them. They come mainly from various reports and articles, as well as from a small number of books on digital influencers and the concept of influencer marketing. The comparative primary and secondary data analysis led to the verification of the adopted research hypotheses. The entire research procedure is shown in Figure 4.

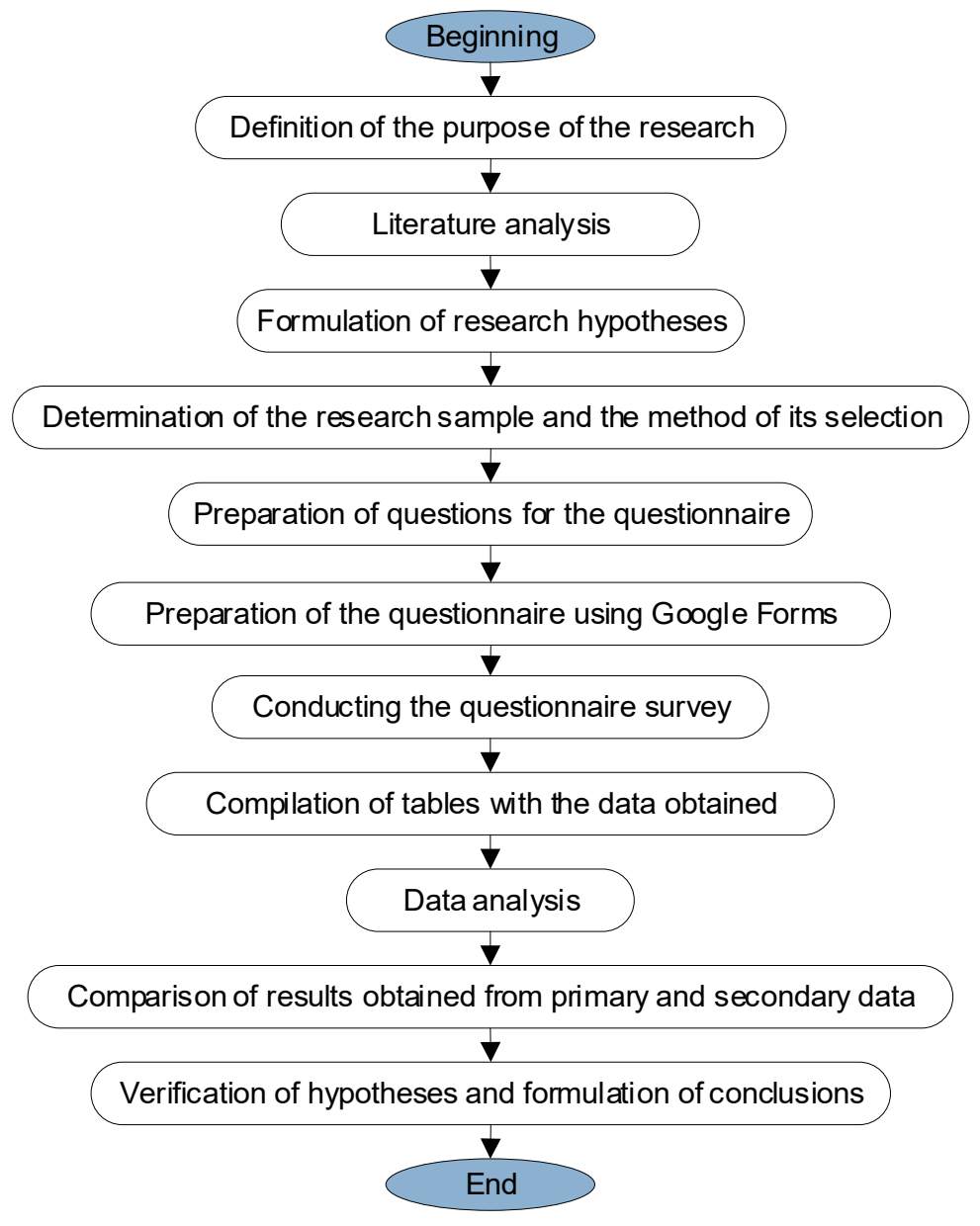

Figure 4. Research procedure (source: own source).

\section{Results}

The main objective of the survey was to gain knowledge about the perception of digital influencers by the respondents, their role in the functioning of the on-line promotional system, and the potential impact on the changes taking place in this system. 
In terms of the way the respondents use the Internet, as representatives of Generation Z, the surveyed group makes use of the Internet access very intensively. On average, over $42 \%(42.6 \%)$ of them are online for more than five hours, and almost $68 \%(67.9 \%)$ of the respondents declared that they are permanently online ('always-on'). The most common social media platforms they use are Facebook, YouTube and Instagram (see Figure 5).

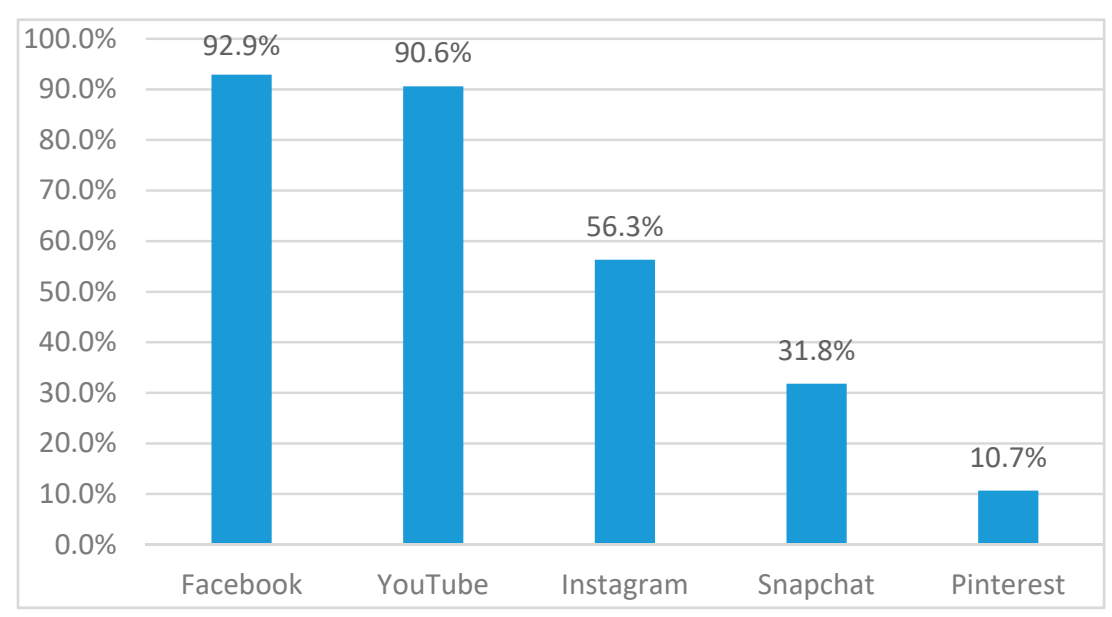

Figure 5. Social media platforms most frequently used by the respondents (source: own research).

The respondents are familiar with the digital influencer concept. More than seventy-six percent of the respondents admitted that they know this concept (76.2\%). At the same time, when asked about the type of influencers with the greatest impact on consumers, the respondents indicated celebrities $(50.1 \%)$ and experts (37.9\%), and vice-versa for peer influencers $(12.1 \%)$.

Regarding the importance of digital influencers in the context of the functioning of the online promotional system, the majority of the respondents agree with the statement that the activities involving them are more convincing than the best personalized digital advertising (see Figure 6).

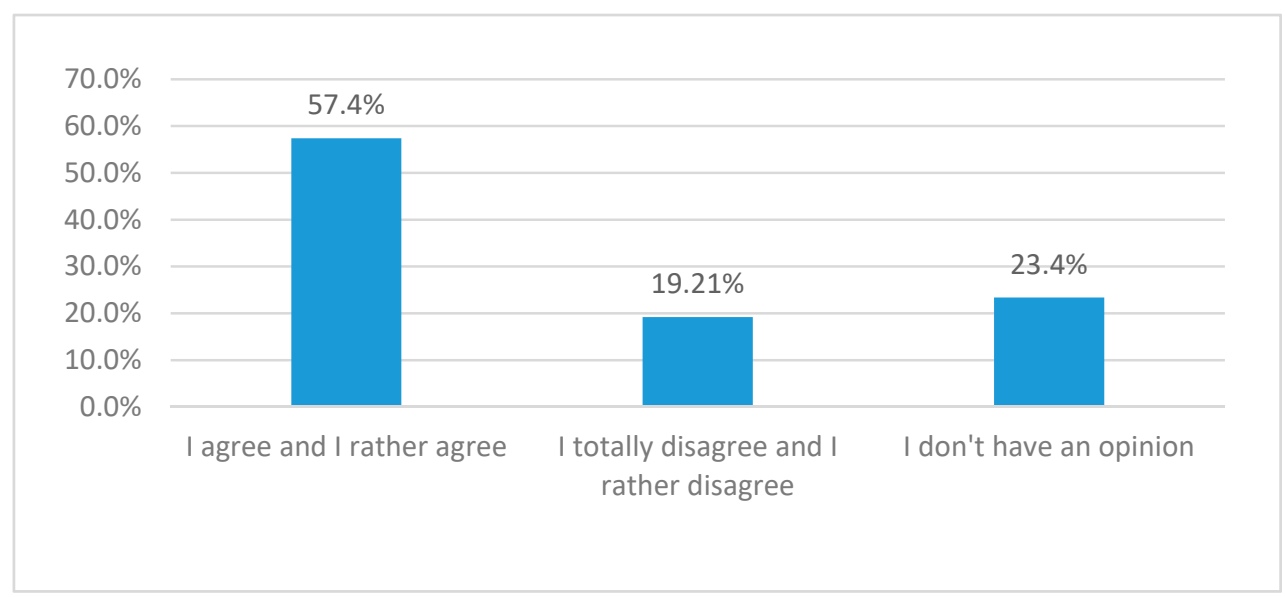

Figure 6. Respondents' assessment of the effectiveness of activities involving digital influencers in comparison with the best personalized advertisements (source: own research).

In terms of the factor determining the effectiveness of digital influencers' actions, the most important aspect turned out to be trust in a particular person as an authority (see Figure 7). 


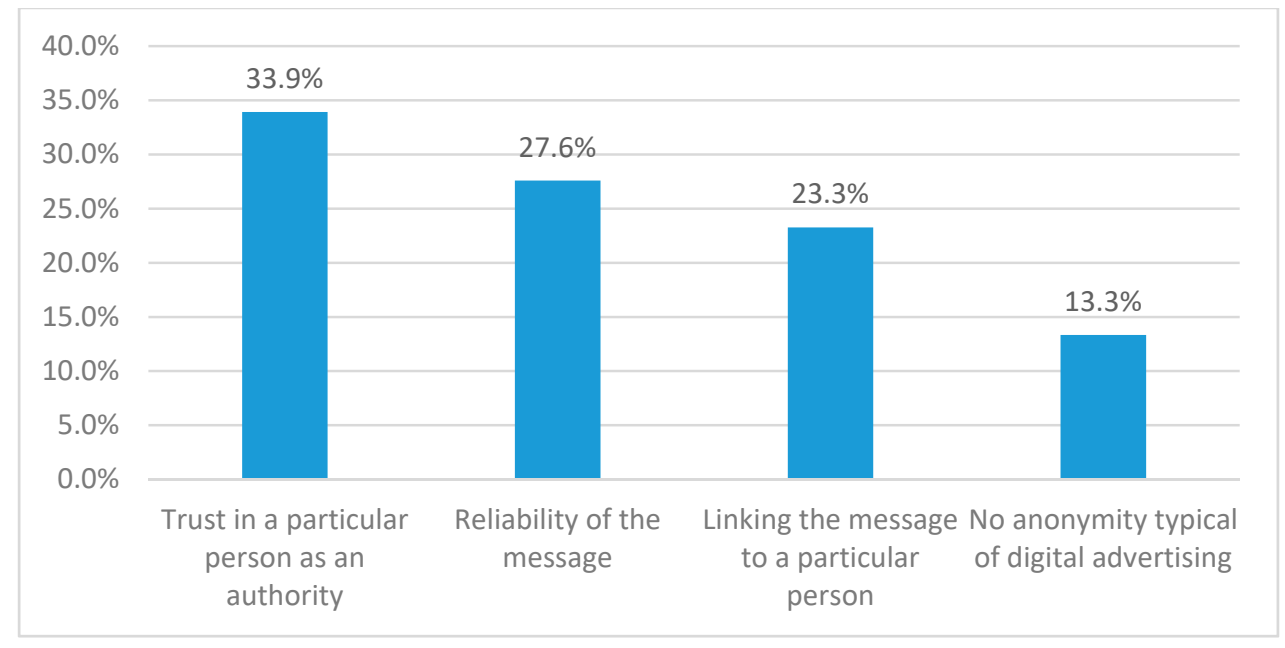

Figure 7. Respondents' assessment of factors determining the effectiveness of activities involving digital influencers (source: own research).

According to the respondents, the most important effect of influencers' actions is, by far, the transfer of information about a specific product or service. On the other hand, they considered it much less important for the influencers to convince people to make purchases (see Figure 8).

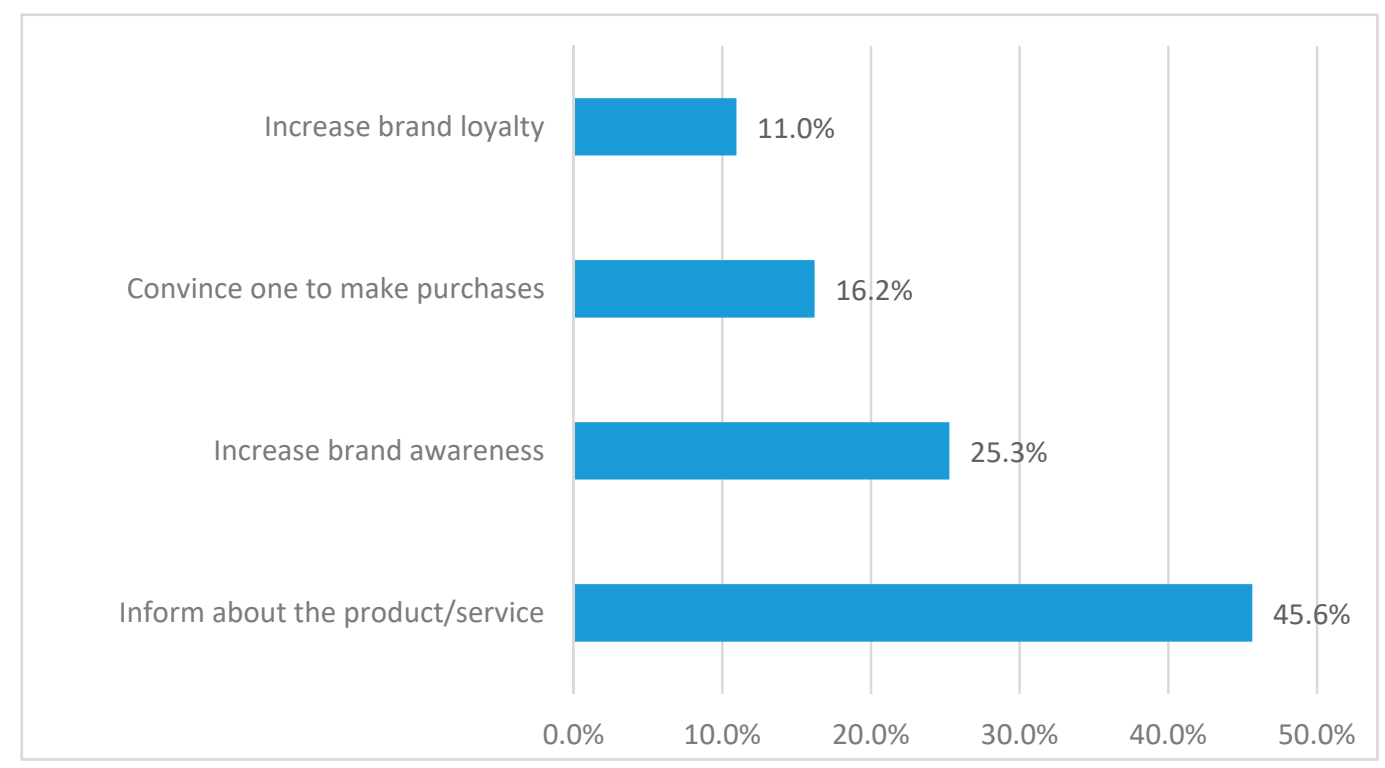

Figure 8. Respondents' assessment of the effects of digital influencers' activities (source: own research).

The latter issue was further analyzed in the next two questions. Regarding the influence of digital influencers on the respondents and their purchasing decisions, almost fifty-four percent $(53.7 \%)$ of them stated that there was no such influence. Over thirty-eight percent of the respondents (38.1\%) were of the opposite opinion. At the same time, when asked whether various forms of influencers' activities in social media have a significant impact on consumers' purchasing decisions, the respondents largely agreed that such a phenomenon takes place (see Figure 9). 


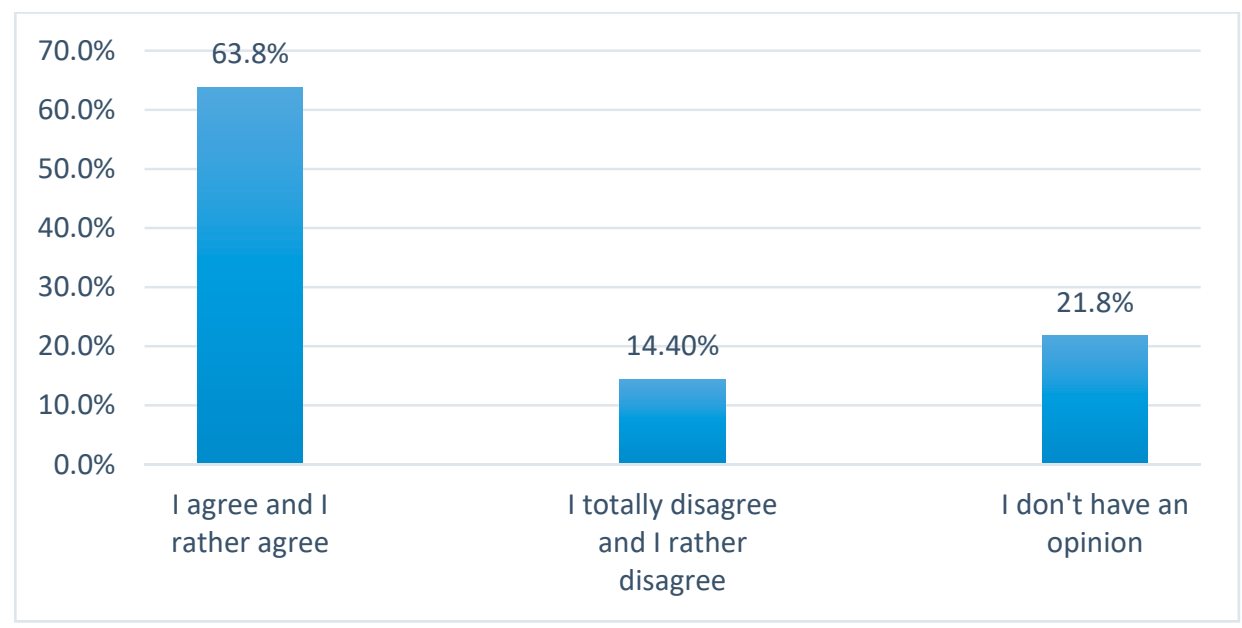

Figure 9. Respondents' assessment of the impact of digital influencers on consumers' purchasing decisions (source: own research).

At the end of the study, two questions were asked about the prospects for the development of activities involving digital influencers. In response to the first of them, the majority of the respondents agree with the statement that the activities involving digital influencers will soon develop at the expense of digital advertising (see Figure 10).

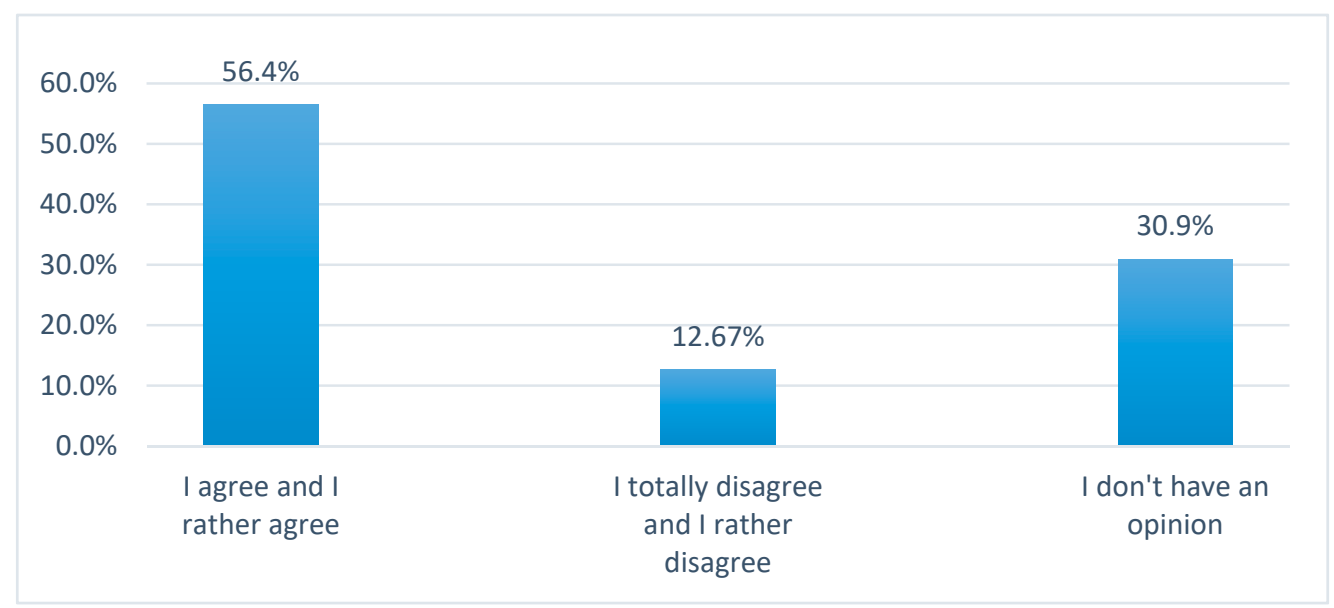

Figure 10. Respondents' assessment of the prospects of activities involving digital influencers in the context of their impact on digital advertising (source: own research).

With reference to the previous question, the respondents were asked about their assessment of the impact of the ad-blocking phenomenon on the development of influencer marketing. In this case, the majority of them agree with the statement that the development of the digital advertisement blocking phenomenon will contribute to organizations' increased efforts to involve digital influencers in on-line promotional activities (see Figure 11). 


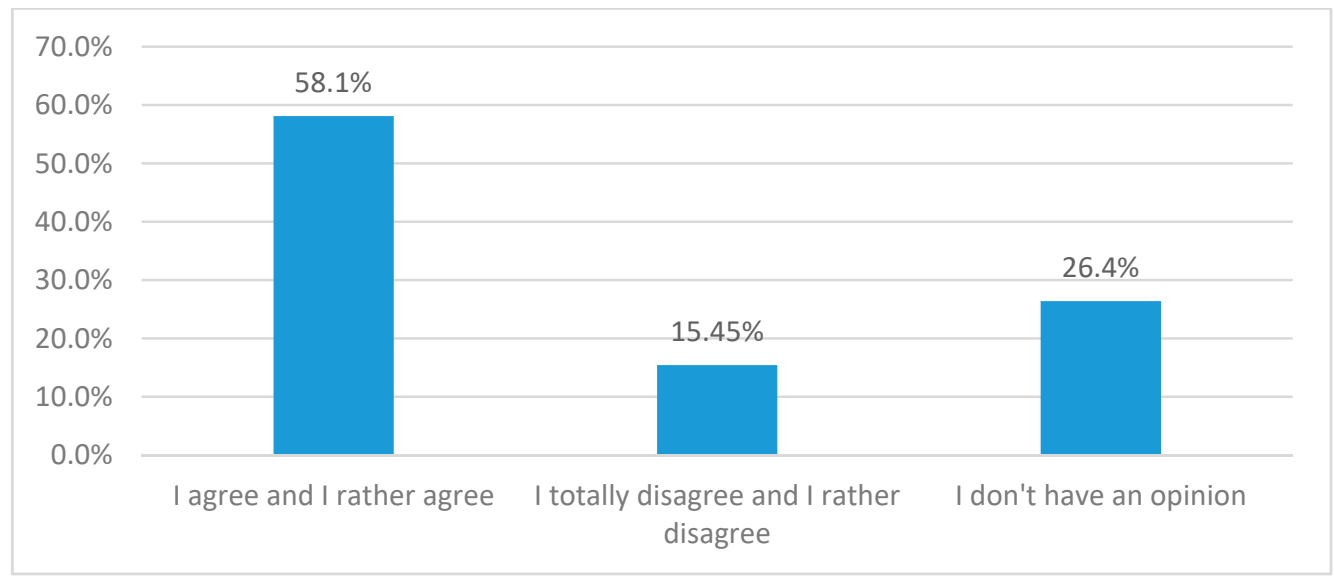

Figure 11. Respondents' assessment of the impact of the development of ad-blocking on the development of activities involving digital influencers (source: own research).

\section{Discussion}

By analyzing the primary data collected during the research and comparing them with the earlier collected secondary data, several important conclusions can be drawn. The assumption that the group selected for the study use Internet access and social media very intensively has been confirmed. Facebook $(92.9 \%)$ and YouTube $(90.6 \%)$ proved to be the most important social platforms in this respect. Instagram, most commonly used for influencer marketing activities (see [39]), attracted much less attention among the respondents (56.3\%). The study also indicates that the respondents are often familiar with the concept of digital influencer (76.2\%). It shows that celebrities (mega-influencers) have the greatest impact on consumers. It is worth noting that organizations intend to gradually leave this group of influencers and divest towards micro-influencers in their campaigns [42].

The majority of the respondents expressed the opinion (Figure 6) that actions involving digital influencers are more effective than the best personalized advertisements. This is consistent with the results of the research carried out by TapInfluence, together with their partners, which indicate the much higher effectiveness of marketing campaigns based on influencers, even in comparison with the best ad banners. In the case of 'average' banner ads, the gap is growing even wider [84].

At the same time, the results of our own research confirm the issue of factors determining the effectiveness of operations involving digital influencers, resulting from the analysis of secondary data. It is clear from both studies that it is the linkage of the message to a specific person that the recipients trust which builds his or her credibility in the context of promoting a specific product or service, which affects the level of brand awareness (Figure 7).

As the analysis of the secondary data indicated the impact of digital influencers' activities on the level of product sales, we also decided to analyze this issue in the primary research. In this case, the results are not entirely clear. On the one hand, the majority of the respondents (53.7\%) stated that digital influencers do not have impact on their own purchasing decisions, but, on the other hand, they assessed that such an influence is generally present for consumers (Figure 9).

The conducted research also indicates that the respondents evaluate that the activities involving digital influencers will develop in the coming years, at the expense of digital advertising (Figure 10). This is consistent with the data presented earlier, which indicate the increasing activity of companies in this area and their growing expenditures on this form of marketing activities. The respondents also agree with the statement that there is a clear correlation between the increased activity involving digital influencers and the development of ad-blocking (Figure 11), which also results from the analysis of secondary data.

Therefore, in the light of the above remarks, it should be concluded that the results obtained from the research do not give grounds for rejecting the earlier adopted research hypothesis H1. 
In order to verify the auxiliary hypotheses $\mathrm{H} 2$ and $\mathrm{H} 3$, Chi Quadrat Tests were performed. They are performed to investigate the relationship between two nominal variables, $X$ and $Y$. They were carried out with the significance level $\alpha=0.05$, checking whether the examined $X$ and $Y$ variables are independent or not. The calculations were performed in the Statistica software.

In case of hypothesis H2, it was checked whether there is a relationship between the manner in which the respondents use the Internet and their knowledge of the digital influencer concept. Testing this hypothesis, the focus was on the group of the respondents who declared that they are constantly online (always-on). The calculations performed to verify hypothesis $\mathrm{H} 2$ are presented in Table 2. As $p>\alpha$, there are no grounds for rejecting the zero hypothesis stating that there is no correlation between the tested characteristics; therefore, hypothesis $\mathrm{H} 2$ has been negatively verified.

Table 2. Chi Quadrat test calculation results for $\mathrm{H} 2$.

\begin{tabular}{|c|c|c|c|}
\hline \multicolumn{4}{|c|}{ Number of Marked Cells >10, Chi^2 Pearson: $1.41720, \mathrm{df}=1, p=0.233864$} \\
\hline $\begin{array}{c}\text { Are you a person } \\
\text { connected all the time to } \\
\text { the Internet }\end{array}$ & $\begin{array}{c}\text { Are you familiar with the } \\
\text { digital influencer concept, } \\
\text { i.e., a person who has a blog, } \\
\text { Facebook, Instagram, } \\
\text { YouTube, Snapchat or other } \\
\text { social media account and } \\
\text { whose opinion can influence } \\
\text { at least several hundred } \\
\text { people? }\end{array}$ & $\begin{array}{c}\text { Are you familiar with the } \\
\text { digital influencer concept, } \\
\text { i.e., a person who has a blog, } \\
\text { Facebook, Instagram, } \\
\text { YouTube, Snapchat or other } \\
\text { social media account and } \\
\text { whose opinion can influence } \\
\text { at least several hundred } \\
\text { people? }\end{array}$ & Row Total \\
\hline (always-on) & No & Yes & \\
\hline Yes & 884,320 & $2,825,680$ & $3,710,000$ \\
\hline No & 395,680 & $1,264,320$ & $1,660,000$ \\
\hline Total & $1,280,000$ & $4,090,000$ & $5,370,000$ \\
\hline
\end{tabular}

As $p \leq \alpha$, the zero hypothesis was rejected, and hypothesis H3 was accepted. Therefore, it was demonstrated that there is a relationship between the respondents' use of ad-block solutions and their opinion about the influence of the ad-blocking phenomenon on the development of activities involving digital influencers. The calculations performed to verify hypothesis $\mathrm{H} 3$ are presented in Table 3. As shown earlier, in Figure 11, over fifty-eight percent of the respondents agree with the statement that the development of the digital ad-blocking phenomenon will result in more widespread use of digital influencers' services in organizations' online promotional activities.

Table 3. Results of Chi Quadrat test calculations for H3.

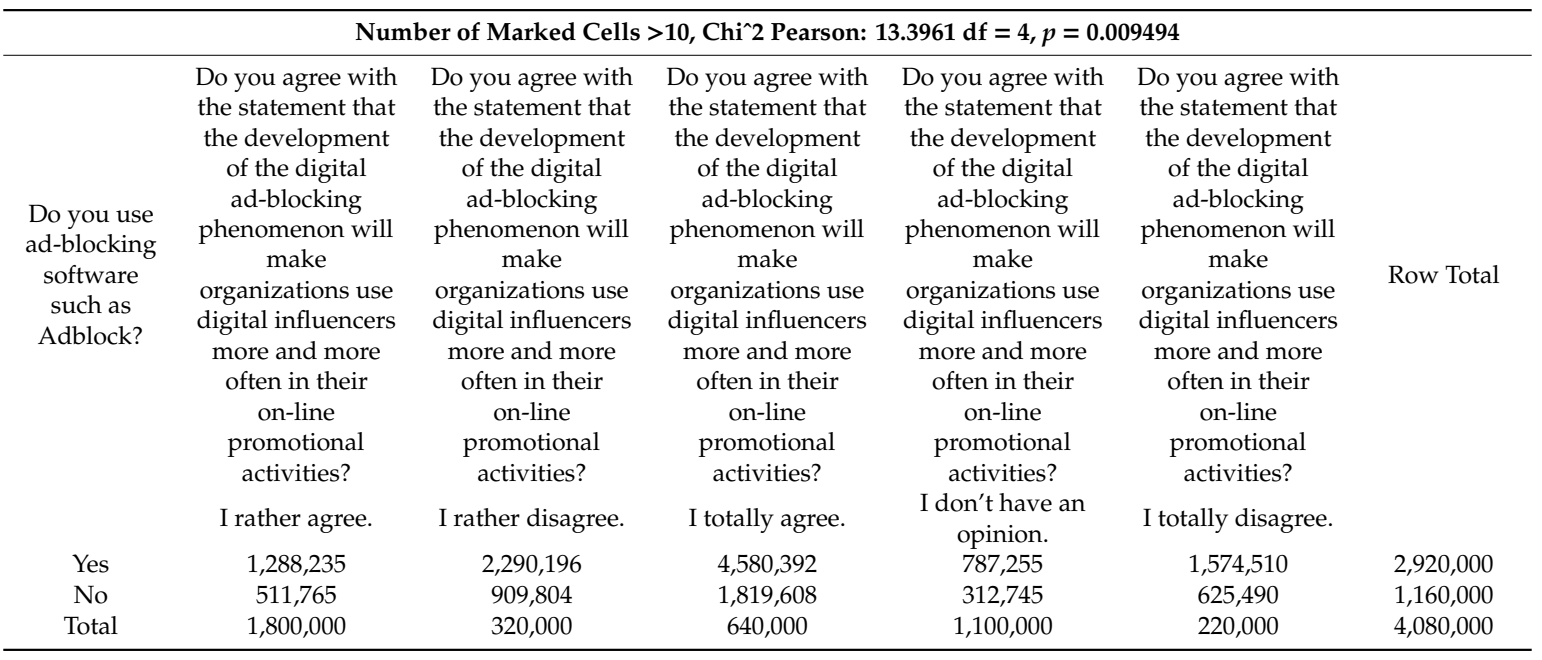




\section{Conclusions}

The study presented in the article addressed digital influencers and the concept of influencer marketing as a new and increasingly important trend in terms of online marketing activities. Influencer marketing has become the fastest growing trend in communication with customers, changing the functioning of entire industries and constituting a critical factor of success for many of them. However, despite the growing role of digital influencers in the marketing activities of organizations and the increasing expenditure of companies on this form of marketing activities, the issue is still understudied. The aim of the study was to determine the function, position and significance of digital influencers in the entire online promotion system, and to state how the concept of influencer marketing influences its sustainable development. The primary research addressed respondents belonging to Generation $Z$; i.e., the group of consumers for whom this form of marketing activities is particularly important. Generation $\mathrm{Z}$ is a growing group of consumers which will be more and more important and influential year by year.

The results of the primary and secondary research confirmed the growing importance of influencers in the functioning of the digital promotion ecosystem and their impact on its further sustainable development. The study identified the main reasons for the development of the concept of influencer marketing and the key issues determining the effectiveness of marketing campaigns conducted with the use of influencers. The threats that may affect the future development of the concept of influencer marketing were also explored.

The main findings of the study are as follows:

1. Digital influencers have more and more influence on the way the promotional activities of modern organizations are conducted, and change the ways the online promotional system works.

2. There are four main types of digital influencers corresponding to the following categories: number of followers, motivation to take action, communication platforms, and the type of their activity.

3. The key criteria for the effectiveness of activities taken by digital influencers include trust in a given person being an authority, the credibility of the message communicated and the link between the message and a specific person.

4. The most important effects of activities taken by digital influencers include the transfer of information about a specific product or service and their impact on increasing brand awareness.

5. Digital influencer activities will develop in the near future at the expense of digital advertising.

6. Due to the development of blocking digital advertising, organizations will use digital influencers in their online promotional activities more widely.

To sum up, the study showed how digital influencers influence the promotional activities of organizations carried out in e-space, and how they can support the existing forms of activities which increasingly less effective due to various phenomena, such as ad-blocking. It also showed how the changes are perceived by consumers belonging to Generation $\mathrm{Z}$.

Even though the primary studies were carried out on a relatively large sample, they have, like any such studies, their obvious limitations. This is mainly due to the fact that they were carried out among people who belong to Generation $\mathrm{Z}$ from a single academic center and country. Therefore, further comparative studies in other domestic and foreign centers are necessary and, indeed, planned. They will include students from four domestic and three foreign universities. Such studies will provide a much broader picture of the phenomenon and its dynamics, and will fill the existing research gap to an even greater extent. In addition to elaborating on and detailing certain issues, such as the real impact of digital influencers on the sale of products or services, such studies should also include respondents' perceptions of such negative phenomena as fake followers or fake sponsored content. In the future, they may have a real impact on the further development of the influencer marketing concept, and may adversely affect the perception of and trust in digital influencers.

Funding: This research received no external funding. 
Conflicts of Interest: The author declares no conflict of interest.

\section{References}

1. GlobalWebIndex. Digital vs. Traditional Media Consumption. Trend Report 2019. Available online: https://www.globalwebindex.com/hubfs/Downloads/Digital_vs_Traditional_Media_Consumption2019.pdf (accessed on 5 October 2019).

2. eMarketer. Digital Marketing Trends 2019 Roundup. Available online: https://on.emarketer.com/rs/ 867-SLG-901/images/eMarketerRoundup_igitalMarketingTrends2019_SponsoredbyMoxie.pdf (accessed on 30 May 2019).

3. Statista. Mobile Advertising Spending worldwide from 2007 to 2021 (in million U.S. dollars). Available online: https://www.statista.com/statistics/303817/mobile-internet-advertising-revenue-worldwide/ (accessed on 19 July 2019).

4. Enberg, J. Digital Ad Spending 2019 Global. Digital Accounts for Half of Total Media Ad Spending Worldwide. eMarketer 2019. Available online: https://www.emarketer.com/content/global-digital-ad-spending-2019 (accessed on 28 March 2019).

5. Wielki, J. The social and ethical aspects connected with e-space development. J. Inf. Commun. Ethics Soc. 2007, 5, 321-333. [CrossRef]

6. Wielki, J.; Grabara, J. The Impact of Ad-Blocking on the Sustainable Development of the Digital Advertising Ecosystem. Sustainability 2018, 10, 4039. [CrossRef]

7. Jerath, K.; Sarvary, M. A Primer on Programmatic Advertising. Columbia CaseWorks 2017, 180, 1-23.

8. Wielki, J. The Impact of the Internet of Things Concept Development on Changes in the Operations of Modern Enterprises. Pol. J. Manag. Stud. 2017, 15, 262-274. [CrossRef]

9. TapInfluence. The Ultimate Influencer Marketing Guide. Available online: https://www.tapinfluence.com/ the-ultimate-influencer-marketing-guide/ (accessed on 3 March 2019).

10. Bhat, F. Ad Blocking's Unintended Consequences; Harvard Business Review: Brighton, MA, USA, 2015. Available online: https://hbr.org/2015/08/ad-blockings-unintended-consequences (accessed on 27 October 2017).

11. Essex, A. The End of Advertising; Spiegel \& Grau: New York, NY, USA, 2017; pp. 3-4.

12. eMarketer. Which Types of Ads Annoy Consumers Most? Available online: https://www.emarketer.com/ content/why-consumers-avoid-ads?ecid=NL1014 (accessed on 29 August 2019).

13. Sołtysik-Piorunkiewicz, A.; Strzelecki, A.; Abramek, E. Evaluation of Adblock Software Usage. Complex. Syst. Inf. Model. Q. 2019, 21, 51-63. [CrossRef]

14. Tudoran, A.A. Why do internet consumers block ads? New evidence from consumer opinion mining and sentiment analysis. Internet Res. 2019, 29, 144-166. [CrossRef]

15. Walrave, M.; Poels, K.; Antheunis, M.L.; Broeck, E.V.D.; Van Noort, G. Like or dislike? Adolescents' responses to personalized social network site advertising. J. Mark. Commun. 2018, 24, 599-616. [CrossRef]

16. He, A. More Research Shows that Consumers May Not Always Want Personalized Marketing Experiences. Available online: https://www.emarketer.com/content/more-research-shows-that-consumers-may-notalways-want-personalized-marketing-experiences (accessed on 23 July 2019).

17. Haddadi, H.; Nithyanand, R.; Javed, M.; Vallina-Rodriguez, N.; Falahrastegar, M.; Powels, J.; De Cristofaro, E.; Murdoch, S. The Adblocking Tug-of-War. Login 2016, 41, 41-43.

18. Nyilasy, G.; Gangadharbatla, H.; Paladino, A. Perceived Greenwashing: The Interactive Effects of Green Advertising and Corporate Environmental Performance on Consumer Reactions. J. Bus. Ethics 2014, 125, 693-707. [CrossRef]

19. Casado-Aranda, L.-A.; Martínez-Fiestas, M.; Sánchez-Fernández, J. Neural effects of environmental advertising: An fMRI analysis of voice age and temporal framing. J. Environ. Manag. 2018, 206, 664-675. [CrossRef]

20. Finch, J. What Is Generation Z, and What Does It Want? Available online: https://www.fastcompany.com/ 3045317/what-is-generation-z-and-what-does-it-want (accessed on 5 April 2015).

21. Bačik, R.; Fedorko, R.; Rigelsky, M.; Sroka, M.; Turáková, A. Perceiving the Advertising in Gender-Generational Characteristics. Pol. J. Manag. Stud. 2018, 18, 44-57. [CrossRef] 
22. Francis, T.; Hoefel, F. 'True Gen': Generation Z and Its Implications for Companies. McKinsey\&Company. 2018. Available online: https://www.mckinsey.com/industries/consumer-packaged-goods/our-insights/truegen-generation-z-and-its-implications-for-companies (accessed on 29 December 2018).

23. Cone Communications. 2017 Cone Gene Z CSR Study: How to Speak Z. Available online: http://www. conecomm.com/2017-cone-gen-z-csr-study-pdf (accessed on 28 December 2018).

24. Kim, A.; McInerney, P.; Rüdiger Smith, T.; Yamakawa, N. What Makes Asia-Pacific's Generation Z different? McKinsey\&Company. 2020. Available online: https://www.mckinsey.com/business-functions/marketingand-sales/our-insights/what-makes-asia-pacifics-generation-z-different (accessed on 30 June 2020).

25. Lou, C.; Kim, H.K. Fancying the New Rich and Famous? Explicating the Roles of Influencer Content, Credibility, and Parental Mediation in Adolescents' Parasocial Relationship, Materialism, and Purchase Intentions. Front. Psychol. 2019, 10. [CrossRef] [PubMed]

26. Fromm, J. Instagram Is a Powerhouse For Gen Z Influencer Marketing. Forbes 2018. Available online: https://www.forbes.com/sites/jefffromm/2018/03/20/instagram-is-a-powerhouse-for-gen-zinfluencer-marketing/\#340edb771d64 (accessed on 20 March 2018).

27. Bonchek, M.; Bapat, V. The Most Successful Brands Focus on Users-Not Buyers; Harvard Business Review: Brighton, MA, USA, 2018. Available online: https://hbr.org/2018/02/the-most-successful-brands-focus-onusers-not-buyers (accessed on 20 January 2019).

28. Van Reijmersdal, E.A.; Van Dam, S. How Age and Disclosures of Sponsored Influencer Videos Affect Adolescents' Knowledge of Persuasion and Persuasion. J. Youth Adolesc. 2020, 49, 1531-1544. [CrossRef] [PubMed]

29. Forbes Communications Council. 12 Marketing Trends to Take Advantage of This Year. Forbes 2018. Available online: https://www.forbes.com/sites/forbescommunicationscouncil/2018/02/14/12-marketing-trends-to-takeadvantage-of-this-year/\#32c4b0e17401 (accessed on 14 February 2018).

30. Roose, K. Don't Scoff at Influencers. They're taking over the World. New York Times. 16 July 2019. Available online: https://www.nytimes.com/2019/07/16/technology/vidcon-social-media-influencers.html (accessed on 16 July 2019).

31. Gundová, P.; Cvoligová, K. Impact of Influencer Marketing on Consumer Behavior. Acta Acad. Karviniensia 2019, 19, 31-41. [CrossRef]

32. Chaffey, D.; Ellis-Chadwick, F. Digital Marketing; Pearson: Harlow, UK, 2016; pp. 11-12.

33. CreatorIQ: Influencer Data Mapping: Unlocking the ROI of Your Influencer Strategy. Available online: https://go.pardot.com/e/534212/IQ-Influencer-Data-Mapping-pdf/5yqhf7/780862800?h= EfTSWO51uVhfOzZrvrffP9vyO3mWMZxmMBfsSU1irpQ (accessed on 29 July 2019).

34. Chief Marketer. The Power of Influencers. Available online: https://cdn.chiefmarketer.com/wpcontent/uploads/2015/11/26966-CM-10232015-Special-Report-PDF-Influencer-Marketing1.pdf (accessed on 29 January 2016).

35. Finley, S. How Online 'Influencers' are Changing the Food Industry. Available online: https://www.bbc.com/ news/business-36271043 (accessed on 13 May 2016).

36. Affendey, L.; Rum, S.; Yaakob, R. Detecting Influencers in Social Media Using Social Network. Analysis (SNA). Int. J. Eng. Technol. 2018, 7, 950-954.

37. Hudson, S.; Kim, A.; Moulton, J. Learning from Digital Threats: Lessons From the Beauty Upstarts. McKinsey Quarterly. Available online: https://www.mckinsey.com/business-functions/mckinsey-digital/our-insights/ learning-from-digital-threats (accessed on 9 January 2019).

38. Agarwal, A.; Brar, J.; Elzinga, D.; Tyagi, A. Marketing Consumer Durables in India: A Journey into the Minds of Digital-Age Consumers. McKinsey\&Company. 2019. Available online: https:/www.mckinsey.com/business-functions/marketing-and-sales/our-insights/marketing-consumerdurables-in-india-a-journey-into-the-minds-of-digital-age-consumers (accessed on 9 August 2019).

39. Backarel, J. To Grow Your Business Abroad, Partner with Local Influencers; Harvard Business Review: Brighton, MA, USA, 2018. Available online: https://hbr.org/2018/09/to-grow-your-business-abroad-partner-with-localinfluencers (accessed on 25 September 2018).

40. Droesch, B. Influencers More Likely to Inspire Gen Zer and Millennial Purchases. eMarketer 2020. Available online: https://www.emarketer.com/content/influencers-more-likely-to-inspire-gen-zer-and-millennialpurchases?ecid=NL1014 (accessed on 30 January 2020). 
41. Audrezet, A.; Charry, K. Do Influencers Need to Tell Audiences They're Getting Paid? Harvard Business Review: Brighton, MA, USA, 2019. Available online: https://hbr.org/2019/08/do-influencers-need-to-tell-audiencestheyre-getting-paid (accessed on 29 August 2019).

42. Influencer Marketing Hub. Influencer Marketing Benchmarking Report: 2020. Available online: https://influencermarketinghub.com/Influencer_Marketing_Benchmark_Report_2020.pdf (accessed on 11 March 2020).

43. Business Insider. Influencer Marketing 2019: Why Brands Can't Get Enough of an \$8 Billion Ecosystem Driven by Kardashians, Moms, and Tweens. Available online: https://www.businessinsider.com/the-2019influencer-marketing-report-2019-7?IR=T (accessed on 15 July 2019).

44. Gutiérrez, V.; Galache, J.; Sánchez, L.; Muñoz, L.; Hernández-Muñoz, J.; Fernandes, J.; Presser, M. SmartSantander: Internet of Things Research and Innovation through Citizen Participation. In The Future Internet; Galis, A., Gavras, A., Eds.; Springer: Heidelberg, Germany, 2013; pp. 79-80.

45. Górecka-Butora, P.; Strykowski, P.; Biegun, K. Influencer Marketing Od A Do Z; WhitePress: Bielsko-Biała, Poland, 2019; pp. 11-53.

46. Vaiciukynaite, E. Men or Women? Neuro-Marketing Study of Social Media Influencers. In Proceedings of the 6th European Conference on Social Media, Brighton, UK, 13-14 June 2019; Popma, W., Francis, S., Eds.; ACPI: Reading, UK, 2019; pp. 280-287.

47. Arrigo, E. Social media marketing in luxury brands. A systematic literature review and implications for management research. Manag. Res. Rev. 2018, 41, 657-679. [CrossRef]

48. Morra, M.; Ceruti, F.; Chierici, R.; Di Gregorio, A.A. Social vs. traditional media communication: Brand origin associations strike a chord. J. Res. Interact. Mark. 2018, 12, 2-21. [CrossRef]

49. Turban, E.; King, D.; Lee, J.; Liang, T.; Turban, D. Electronic Commerce A Managerial and Social Networks Perspective; Springer: Cham, Switzerland, 2015; p. 311.

50. Kupfer, A.; Pahler vor der Holte, N.; Kubler, R.; Hennig-Thurau, T. The Role of the Partner Brand's Social. Media Power in Brand Alliances. J. Mark. 2018, 82, 25-44. [CrossRef]

51. Hopper. Instagram Rich List 2018. Available online: https://www.hopperhq.com/blog/instagram-rich-list/ niche/celebrity/ (accessed on 28 March 2019).

52. Silva, M.J.D.B.; De Farias, S.A.; Grigg, M.K.; Barbosa, M.D.L.D.A. Online Engagement and the Role of Digital Influencers in Product Endorsement on Instagram. J. Relatsh. Mark. 2019, 19, 133-163. [CrossRef]

53. Schaffer, N.I. The Age of Influence; HarperCollins Leadership: New York, NY, USA, 2020; pp. $25-35$.

54. Bizzi, L.; Labban, A. The double-edged impact of social media on online trading: Opportunities, threats, and recommendations for organizations. Bus. Horiz. 2019, 62, 509-519. [CrossRef]

55. Panyi, K.; Varga, A. The Possibilities of Influencer Marketing in FMCG Sector. In Proceedings of the International Conference on University-Based Entrepreneurship and Regional Development: Theory, Empirics and Practical Implementation (ICUBERD), Pécs, Hungary, 30 November-1 December 2017; Györkő, D., Kleschné, V., Bedő, Z., Eds.; University of Pécs: Pécs, Hungary, 2017; pp. 124-135.

56. Schouten, A.; Janssen, L.; Verspaget, M. Celebrity vs. Influencer endorsements in advertising: The role of identification, credibility, and Product-Endorser fit. Int. J. Adv. 2020, 39, 258-281. [CrossRef]

57. Lin, H.; Bruning, P.; Swarna, H. Using online opinion leaders to promote the hedonic and utilitarian value of products and services. Bus. Horiz. 2018, 61, 431-442. [CrossRef]

58. Litterio, A.; Nantes, E.; Larrosa, J.; Gómez, L. Marketing and social networks: A criterion for detecting opinion leaders. Eur. J. Manag. Bus. Econ. 2017, 26, 347-366. [CrossRef]

59. Kannan, P.; Li, H. Digital marketing: A framework, review and research agenda. Int. J. Res. Mark. 2017, 34, 22-45. [CrossRef]

60. TapInfluence. What Do I Need to Know About Influencer Marketing? Available online: http://pages.tapinfluence.com/hubfs/2017\%20Predictions/What_Do_I_Need_to_Know_IM.pdf (accessed on 14 March 2018).

61. Juganaru, R. The Increasing Influence of the Word 'Influencer'. Available online: https://blog.oxforddictionaries. com/2018/05/09/the-increasing-influence-of-the-word-influencer/ (accessed on 9 May 2018).

62. Google Trends. Influencer. Available online: https://trends.google.pl/trends/explore?date=today $\% 205-y \& q=$ Influencer (accessed on 7 October 2019).

63. Google Trends. Influencer marketing. Available online: https://trends.google.pl/trends/explore?date=today $\%$ 205-y\&q=\%2Fm\%2F026bgmq (accessed on 28 October 2019). 
64. Kartajaya, H.; Kotler, P.; Setiawan, I. Marketing 4.0: Moving from Traditional to Digital; Wiley: East Orange, NY, USA, 2017; p. 132.

65. Babin, J.; Hulland, J. Exploring online consumer curation as user-generated content. Span. J. Mark. 2019, 23, 325-338. [CrossRef]

66. Törhönen, M.; Sjöblom, M.; Hassan, L.; Hamari, J. Fame and fortune, or just fun? A study on why people create content on video platforms. Int. Res. 2019, 30, 165-190. [CrossRef]

67. Gräve, J.-F. What KPIs Are Key? Evaluating Performance Metrics for Social Media Influencers. Soc. Media Soc. 2019, 5, 1-9. [CrossRef]

68. Cotter, K. Playing the visibility game: How digital influencers and algorithms negotiate influence on Instagram. New Media Soc. 2019, 21, 895-913. [CrossRef]

69. Mediakix Team. What Is A Macro-Influencer? Available online: http://mediakix.com/2017/08/what-is-amacro-influencer-definition/ (accessed on 24 August 2017).

70. Mediakix Team. What is A Micro-Influencer? Available online: http://mediakix.com/2016/06/microinfluencers-definition-marketing/ (accessed on 29 January 2017).

71. Jones, K. Is Influencer Marketing the Next Big Thing in Online Sales? Available online: https://www.americanexpress.com/en-us/business/trends-and-insights/articles/is-influencer-marketingthe-next-big-thing-in-online-sales/ (accessed on 16 November 2016).

72. Leon, G.; Sanchez-Cartas, J. On "Influencers" and their impact on the diffusion of digital platforms. In Highlights of Practical Applications of Agents, Multi-Agent Systems, and Complexity: The PAAMS Collection. PAAMS 2018; Communications in Computer and Information Science; Bajo, J., Corchado, J.M., Navarro, E., Osaba Icedo, E., Mathieu, P., Hoffa-Dabrowska, P., Del Val, E., Giroux, S., Castro, A.J.M., Sánchez-Pi, N., et al., Eds.; Springer: Cham, Switzerland, 2018; Volume 887, pp. 210-222.

73. Hotsuite. Digital 2019. Global Digital Yearbook. Available online: https://p.widencdn.net/kqy7ii/Digital2019Report-en (accessed on 5 May 2019).

74. Zak, S.; Hasprova, M. The role of influencers in the consumer decision-making process. In Proceedings of the 19th International Scientific Conference Globalization and Its Socio-Economic Consequences 2019-Sustainability in the Global-Knowledge Economy, Rajecke Teplic, Slovakia, 9-10 October 2019; Kliestik, T., Ed.; Curran Associates: New York, NY, USA; pp. 526-532.

75. TapInfluence. The Influencer Marketing Manifesto. Available online: https://cdn2.hubspot.net/hubfs/1882019/ TapInfluence/Resources/1020\%20-\%20Influencer_Marketing_Manifesto.pdf (accessed on 23 February 2019).

76. TapInfluence. Unleash the Power of Influencer Content. Available online: https:/www.tapinfluence. comhubfs/Unleash_The_Power_Of_Influencer_Content8_Things.pdf (accessed on 30 December 2018).

77. Huff, T. 6 Big Benefits of Using Influencer Marketing in Your Social Strategy. Social Media Today 2017. Available online: https://www.socialmediatoday.com/social-networks/6-big-benefits-using-influencermarketing-your-social-strategy (accessed on 9 May 2017).

78. Padhiyar, R. Fundamentals of Digital Marketing; Pan-Altus Educare: Ghaziabad, India, 2020; pp. 50-51.

79. TapInfluence. Sales Effect Study: Influencer Marketing. Available online: http://pages.tapinfluence.com/ hubfs/Nielsen_WhiteWave_Study/1009_-_Nielsen_Study_Case_Study.pdf (accessed on 12 March 2017).

80. HubSpot. $71 \%$ More Likely to Purchase Based on Social Media Referrals. Available online: https://blog.hubspot.com/blog/tabid/6307/bid/30239/71-More-Likely-to-Purchase-Based-on-SocialMediaReferralsInfographic.aspx?_hstc=60045554.7f1a1f454d589ae3295046c156fcf6b1.1557252871235. $1557252871235.1557252871235 .1 \& \_$_hssc $=60045554.1 .1557252871238 \&$ \& hsfp $=13092653$ (accessed on 9 January 2012).

81. Olenski, S. Are Brands Wielding More Influence In Social Media Than We Thought? Forbes 2012. Available online: https://www.forbes.com/sites/marketshare/2012/05/07/are-brands-wielding-more-influence-in-socialmedia-than-we-thought/\#1a887b0571e1 (accessed on 7 May 2012).

82. Rakuten Marketing. 2019 Influencer Marketing Global Survey Consumers. Available online: https:/www.iab.com/wp-content/uploads/2019/03/Rakuten-2019-Influencer-Marketing-ReportRakuten-Marketing.pdf (accessed on 30 September 2019).

83. Influencer Marketing Hub. Influencer Marketing Benchmarking Report: 2019. Available online: https://influencermarketinghub.com/IM_Benchmark_Report_2019.pdf (accessed on 15 March 2019). 
84. TapInfluence. Influencer Marketing Drives 11x More ROI vs. All Other Forms of Digital Media. Available online: http://pages.tapinfluence.com/hubfs/Nielsen_WhiteWave_Study/1009_-_Nielsen_Study_Infographic. pdf (accessed on 29 January 2017).

85. Linqia. The State of Influencer Marketing 2018. Available online: http://www.linqia.com/wp-content/ uploads/2017/12/Linqia-The-State-of-Influencer-Marketing-2018.pdf (accessed on 9 January 2018).

86. eMarketer. Global Influencer Marketing 2019. Available online: https://www.emarketer.com/content/globalinfluencer-marketing-2019 (accessed on 5 March 2019).

87. Influencer Marketing Hub. Influencer Fraud. Available online: https://influencermarketinghub.com/ Influencer-Fraud.pdf (accessed on 15 January 2019).

88. O'Malley, G. Fake Followers Eating Into Brands' Influencer Marketing Budgets. MediaPost 2019. Available online: https://www.mediapost.com/publications/article/331748/fake-followers-eating-into-brandsinfluencer-mark.html (accessed on 8 February 2019).

89. Lorenz, T. Rising Instagram Stars Are Posting Fake Sponsored Content. The Atlantic 2018. Available online: https://www.theatlantic.com/technology/archive/2018/12/influencers-are-faking-brand-deals/578401/ (accessed on 18 December 2018).

90. Mediakix. 11 Influencer Marketing Challenges in 2019? Available online: http://mediakix.com/influencermarketing-challenges/ (accessed on 1 April 2019).

91. Klein, J. 38\% of Gen Z And Millennials Trust Digital Influencers, Says Fullscreen Study. Tubefilter 2018. Available online: https://www.tubefilter.com/2018/03/27/gen-z-millennials-trust-influencers-fullscreen/ (accessed on 27 March 2018).

(C) 2020 by the author. Licensee MDPI, Basel, Switzerland. This article is an open access article distributed under the terms and conditions of the Creative Commons Attribution (CC BY) license (http://creativecommons.org/licenses/by/4.0/). 